\title{
Aluetutkimus etäyhteyksien vuonna
}

Mitä kaikkea Venäjään ja itäiseen Eurooppaan liittyvää tällä hetkellä maailmalla tutkitaan? Yksi tapa hahmottaa sitä, miten Venäjä ja itäistä Eurooppaa käsittelevä tutkimus etenee, on tutustua alan keskeisten tieteellisten lehtien tarjontaan ja etenkin niiden teemanumeroihin. Toki lehtien julkaisuprosessit ovat pitkiä, jopa useiden vuosien mittaisia, mikä johtaa siihen että lehtien sisällysluettelot eivät välttämättä kerro juuri tämän hetken suurimmista tutkimustrendeistä. Suuntaa antavia ne kuitenkin ovat, ovathan tutkimusprojektitkin usein pitkiä ja tutkimuskeskuksilla ja tutkijoilla vakiintuneita tutkimuksellisia kiinnostuksenkohteita.

Nopealla katsauksella muutamiin monitieteisiin yhteiskunnallisen ja humanistisen alan englanninkielisiin lehtiin, erityisesti niiden erikoisnumeroihin, löytyy jo laaja kattaus aiheita. Europe-Asia Studies -lehdessä on käsitelty muun muassa poliittista revisionismia, entisen Neuvostoliiton alueen konfliktipotentiaalia, sekä displacement-näkökulmasta Ukrainan alueella tapahtuvia sotatoimia. Post-Soviet Affairs -lehden yhdessä teemanumeroista on tarkasteltu Venäjän kehitystä poliittisen taloustieteen näkökulmasta, toisessa poliittisia protesteja entisen Neuvostoliiton alueella. Demokratizatsiya-lehdessä on ollut tänä vuonna teemanumerot lainsäädännöstä sekä paikallismediasta, molemmissa tarkastelun kohteena entisen Neuvostoliiton alueen maat. Slavic \& East European Journal on käsitellyt muun muassa yksilöiden ja kansojen rajat ylittäviä identiteettejä kylmän sodan aikana ja sen jälkeen sekä slavistiikan tutkimusta Itä-Aasiassa ja Latinalaisessa Amerikassa.

Tulevista teemanumeroista ei kaikkien lehtien sivuilta löydy tietoa, mutta joitakin erilaisia kiinnostavia erikoisnumeroiden aihioita olen onnistunut haarukoimaan isoista ja pienemmistäkin julkaisuista. Europe-Asia Studiesiin on tulossa vuonna 2021 teemanumerot ainakin laillisuudesta ja turvallisuudesta sekä nuorisopolitiikasta. Puolalainen Studia Rossica Posnaniensia on julkaisemassa vuonna 2021 tilan käsitteeseen liittyvän teemanumeron, jossa tarkastelun kohteena ovat venäläiset kulttuuritekstit. Unkarilainen Hungarian Journal of English and American Studies (HJEAS) suunnittelee vuodelle 2022 erikoisnumeroa keski-ja itäeurooppalaisten muutosta Kanadaan. Demokratizatsiya-lehden niin ikään vuodelle 2022 suunniteltu teemanumero käsittelee afrikkalaisamerikkalaisia ja afrikkalaisia Neuvostoliitossa ja nykypäivän afrikanvenäläisiä.

Venäjän ja itäisen Euroopan tutkimuksessa on toistaiseksi näkynyt julkaisupuolella vain vähän koronaviruspandemiaan liittyvät aiheet, mutta konferensseissa tämä suuresti yhteiskuntiin vaikuttava teema jo näkyy. Osallistuin lokakuussa Moskovan valtionyliopiston journalistisen tiedekunnan järjestämään vuosittaiseen konferenssiin, jossa tänä vuonna teemana olivat muun muassa median globalisaation ja paikallisuuden trendit. Esitelmissä näkyi esimerkiksi korona-aikaan liittyvä median käyttötapojen muutos, jota brittiläisen 
Loughboroughin yliopiston professori Sabina Mihelj tutkii osana poliittista polarisaatiota ja demokratiaa itäisessä ja Keski-Euroopassa tarkastelevaa hanketta.

Tämä konferenssi toteutui etäyhteyksin, joten Moskovaan matkustamisen sijaan oman paneelikeskustelun vetäminenkin onnistua kotoa kannettavan tietokoneen ääreltä. Myös Venäjän ja itäisen Euroopan tutkimuksen suurin vuosittainen konferenssi ASEEES toteutui tänä syksynä virtuaalisesti. Muutoin monia konferensseja on siirretty vuodelta 2020 seuraavalle vuodelle, ja osa on jo suunniteltu järjestettäväksi etäyhteyksin tai hybridimuodossa, niin että osa osallistujista kokoontuu fyysiselle konferenssipaikalle ja osa tulee paikalle virtuaalisesti. Suurista konferensseista ICCEES on tarkoitus järjestää kokonaan virtuaalisena elokuussa 2021. Suomalainen Aleksanteri-konferenssi siirrettiin syksyltä 2020 syksylle 2021, ja myös se pidetään etäyhteyksin. Brittiläinen BASEES puolestaan on perunut paitsi vuoden 2020, myös vuoden 2021 konferenssinsa ja aikoo järjestää seuraavan ison konferenssin vasta vuonna 2022 Cambridgessa.

Palatakseni teemanumeroihin, täällä Idäntutkimuksessa vuoden 2021 numeroiden suunnittelu on hyvässä vauhdissa. Ensimmäisenä suunnitelmissa on pohjoista kirjallisuutta käsittelevä teemanumero, ja vuoden toisessa numerossa on vapaa teema. Kolmannen numeron teemana on teknologia ja neljännen rakkaus. Vuoden toisesta numerosta eteenpäin on hyvin tilaa myös uusille juttuehdotuksille, joten jos olet miettinyt Idäntutkimuksessa julkaisemista, kannattaa tutustua tässä numerossa julkaistuun kirjoittajakutsuun ja lähettää meille toimituskuntaan viestiä.

Helsingissä 2.12.2020

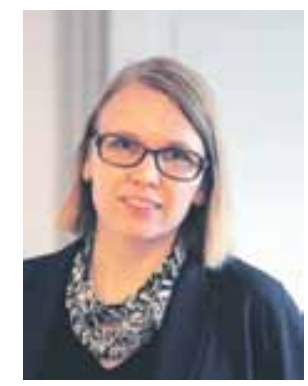

Katja Lehtisari 